\title{
BIOGENIC SYNTHESIS OF IMPORTANT ENVIRONMENTAL MINERALS: MAGNESIUM PHOSPHATE COMPOUNDS AND PERSPECTIVES
}

\author{
Nelson Durán ${ }^{\mathrm{a}, *}$ and Wagner J. Favaro ${ }^{\mathrm{b}, \#}$ \\ a'Laboratório de Química Biológica, Instituto de Química, Universidade Estadual de Campinas, 13083-970, Campinas - SP, Brasil \\ bepartamento de Biologia Estrutural e Funcional, Instituto de Biologia, Universidade Estadual de Campinas, 13083-865 Campinas \\ - SP, Brasil
}

Recebido em 18/12/2017; aceito em 22/01/2018; publicado na web em 22/02/2018

\begin{abstract}
The ecological processes in which metabolites with industrial or medical applications are produced are of great importance. Magnesium plays many important roles in environmental and medical applications. Phosphorus is obtained by mining. It is estimated to have a very limited half-life and expected to be depleted as a resource in 100 years. Its recovery by mining and subsequent marketing as phosphate has important environmental implications. These processes are part of an important recovery technology. Bacteria have contributed to the formation of minerals since the advent of life on Earth. Bacterial and/or fungal biomineralizations play a critical role in biogeochemical cycles. These processes have important technological and environmental applications. In many past publications dealing with bacterial and fungal recovery of phosphates as insoluble products, magnesium played an important role. This is a review of recent progress in the microbial recovery of biogenic magnesium phosphate compounds, their importance, and their roles in treatment of several human diseases.
\end{abstract}

Keywords: magnesium; phosphate; biosynthesis; biogenic bacteria; fungi; yeast; infectious diseases; cancer; immunology; immunotherapy.

\section{INTRODUCTION}

Phosphate occurs widely distributed in nature. All forms of life include it. The human body contains around 500 grams of phosphorus. It is a chemical constituent of adenosine triphosphate (ATP), an important component of energy metabolism in living beings. In animals, it is found in blood, nerves, and muscles. It is also found in their bones and teeth in the form of calcium phosphate as hydroxyapatite, $\mathrm{Ca}_{2}(\mathrm{OH})\left(\mathrm{PO}_{4}\right)_{3}$, and fluoroapatite, $\mathrm{Ca}_{5}(\mathrm{~F}, \mathrm{OH})\left(\mathrm{PO}_{4}\right)_{3}$. In food, phosphorus occurs as organic phosphate, dicalcium- and tricalcium phosphate ${ }^{1}$ and ferric phosphate. Among commercial products, phosphorus occurs in pharmaceuticals, detergents, water softeners, and denitrifiers, among others. On a practical scale, phosphate-containing products are mainly formed from phosphoric acid $\left(\mathrm{H}_{3} \mathrm{PO}_{4}\right)^{2-5}$

Phosphate accumulates mainly as polyphosphate. Phosphoruscontaining storage compounds may be inorganic or organic. The form of those of microbial origin depends on the microorganism involved. Orthophosphate $\left(\mathrm{PO}_{4}{ }^{3-}\right)$ compounds of low-solubility are the simplest forms of phosphorus accumulation.

Magnesium phosphates are important sources of magnesium. In magnesium deficiency disease, phosphate-containing prodrugs (medication that, after administration, is metabolized into a pharmacologically active compound) and liberates phosphate are widely used as sources of this element for a specific target. ${ }^{6}$

It is known that magnesium has crucial functions in numerous biological processes and at different levels: First, as a cofactor in ATP utilization in various enzymatic reactions, second, as a stabilizer of membranes, nucleic acid, and complex proteins, and third, as a molecular marker. Thus, magnesium occupies an important position in controlling cell survival and cell growth. Increased consumption of magnesium in the human diet is associated with lowering the risk

*e-mail: duran@iqm.unicamp.br

\#e-mail: favarowj@unicamp.br of a heart attack, heart failure, diabetes, and other causes of mortality. These effects of magnesium support the notion that increasing the magnesium content of the diet could be beneficial to human health. ${ }^{7}$ Magnesium consumed alone may improve survival following breast cancer. The concurrent influence of calcium may be greater at a high Ca:Mg ratio. ${ }^{8}$

Recent discoveries indicate that high levels of magnesium in the blood are associated with low risk of prostate cancer (high-grade). A low $\mathrm{Ca}: \mathrm{Mg}$ ratio has been associated with high risk of prostate cancer, suggesting that the relationship between calcium and magnesium plays an important role in progression and pathogenesis of this type of cancer. ${ }^{9}$ High levels of calcium in conjunction with low levels of magnesium and phosphorus appear to increase the risk of bladder cancer. It has been reported that a high consumption of calcium could imply magnesium deficiency. ${ }^{10}$

Low intracellular concentration of $\mathrm{Mg}^{2+}$ has been associated with exacerbation of carcinogenesis and metastases. ${ }^{11}$ Conditions of low $\mathrm{Mg}^{2+}$ and reduced activity of DNA repair mechanisms decrease DNA protection against damage by oxidative stress. Low dietary intake of $\mathrm{Mg}^{2+}$ has been associated with the risk of several types of cancers. Colon cancer has been associated with low intake of $\mathrm{Mg}^{2+}$. $^{12-14}$

\section{Phosphate accumulation in organisms}

Archaea can precipitate $\mathrm{Mg}_{2}(\mathrm{OH}) \mathrm{PO}_{4} \bullet 4 \mathrm{H}_{2} \mathrm{O}$ (e.g., Halorubrum distributum and Halobacterium salinarium). These kinds of strains concentrate phosphorus from an aqueous solution during the growth phase. It is known that intracellular $\mathrm{NH}_{4} \mathrm{MgPO}_{4} \bullet 6 \mathrm{H}_{2} \mathrm{O}$ is accumulated in Brevibacteria. ${ }^{15}$ Cyanobacteria concentrate phosphorous in their sheaths in association with calcium.

The second type of accumulation of phosphorus is in the form of organic compounds associated with calcium. Bacteria synthesize a compound associated with teichoic acid and polyol/glycosylic polyol residues linked by phosphodiester bonds. This compound probably constitutes a phosphate reserve. The yeast Kuraishia capsulata stores 
phosphate as phosphomannan. ${ }^{16}$ However, polyphosphate is the most important phosphorus reserve in microorganisms, containing three to a hundred phosphate units. In addition to being a polymeric reserve, some polyphosphate regulates enzymatic activities, and also the expression of genes controlling adaptation to stress. ${ }^{16}$ Some of these phosphates are important as food complements. ${ }^{17,18}$

Phosphate accumulating microorganisms (PAOs) have been detected and they accumulate $\mathrm{P}$ in their sheaths, combined with calcium, as phosphate storage. Acinetobacter was present in an enhanced biological phosphorus removal (EBPR) plant, but new studies using culture-independent techniques demonstrated that this bacterium had only a small but important effect on the removal process. Microlunatus phosphovorus was also isolated and it was suggested to be a PAO, but it did not exhibit a characteristic presence of polyhydroxyalkanoate (PHA) granules. ${ }^{19}$

Candidatus accumulibacter phosphatis was identified by molecular techniques and assigned to a subclass of PAO that is involved in phosphorus removal on a laboratory scale, but it was never isolated in pure culture. ${ }^{19}$

\section{Biogenic synthesis of magnesium phosphate compounds}

\section{$\mathrm{NH}_{4} \mathrm{MgPO}_{4} \cdot 6 \mathrm{H}_{2} \mathrm{O}$}

$\mathrm{NH}_{4} \mathrm{MgPO}_{4} \cdot 6 \mathrm{H}_{2} \mathrm{O}$ is an insoluble phosphate that has received attention from microbiologists. This is probably because different types of bacteria produce this mineral under laboratory conditions, and also because of the relationship of this compound to kidney calculi and to urinary infections. ${ }^{20}$

Many of these complex phosphates are produced biogenically. Robinson $^{21}$ was the first who described the bacterial synthesis of this compound. Diverse species of bacteria, such as Staphylococcus aureus, ${ }^{22}$ Pseudomonas calciprecipitans, ${ }^{23}$ Proteus, ${ }^{24}$ Ureaplasma urealiticum $^{25}$ and certain strains of the genera Pseudomonas, Flavobacterium and Arthrobacter, ${ }^{26}$ were known for their ability to produce this compound. Okorokov et al. ${ }^{27}$ reported the synthesis of polymeric phosphate of magnesium by the fungi Penicillium chrysogenum and Endomyces magnusii and by yeast Saccharomyces cerevisiae. Fungi also contain a form of bound magnesium, a polymeric magnesium phosphate $\left(\mathrm{PO}_{\mathrm{Mg}}\right)$, which apparently participates in the control of the level of free $\mathrm{Mg}^{2+}$ in Penicillium chrysogenum Q-176. The growth of Penicillium chrysogenum Q-176 and 140A and of Endomyces magnusii was proportional to the concentration of free $\mathrm{Mg}^{2+}$.

The intracellular $\mathrm{Mg}^{2+}$ concentration in these fungi was greater than in the external medium (values normalized to external $\mathrm{Mg}^{2+}$ concentration) (up to 1:110 for Saccharomyces cerevisiae; 1:120 for Endomyces magnusii; 1:25 for Endomyces magnusii in the presence of yeast extract; 1:1300 for Penicillium chrysogenum 140A). These intracellular concentrations were probably achieved by active transport. The authors suggested that it was important to note that the high external $\mathrm{Mg}^{2+}$ concentrations did not affect intracellular $\mathrm{Mg}^{2+}$ concentrations, although in the case of Endomyces magnusii a gradient as great as 18:1 may exist. ${ }^{27}$

Perez-Garcia et al. ${ }^{26,28}$ reported the synthesis of $\mathrm{NH}_{4} \mathrm{MgPO}_{4} \cdot 6 \mathrm{H}_{2} \mathrm{O}$ from bacteria Arthrobacter $s p$. and from Pseudomonas sp. A marine bacterium Pseudomonas calciprecipitans was also able to produce $\mathrm{NH}_{4} \mathrm{MgPO}_{4} \cdot 6 \mathrm{H}_{2} \mathrm{O}$. ${ }^{23}$ The production of $\mathrm{NH}_{4} \mathrm{MgPO}_{4} \cdot 6 \mathrm{H}_{2} \mathrm{O}$ by myxobacterium Myxococcus coralloides has been reported by Gonzalez-Muñoz et al. ${ }^{29}$ Its production by Myxococcus xanthus has been reported by Ben Omar et al..$^{30}$ and Da Silva et al. ${ }^{31}$ It was assumed that $M$. xanthus and $M$. coralloides, like other organisms with this capacity, formed this compound metabolically. The crystallization of the product was facilitated by adding $\mathrm{NH}_{4}^{+}$to the reaction mixture and allowing for an increase in $\mathrm{pH} .{ }^{26}$ Some of the $\mathrm{NH}_{4}{ }^{+}$was a byproduct of nitrogen metabolism of the bacteria but Gonzalez-Muñoz et al. ${ }^{29}$ and Ben Omar et al. ${ }^{32}$ found that even with an increase in $\mathrm{pH}$ of the medium, $\mathrm{NH}_{4}^{+}$production was insufficient for the formation of $\mathrm{NH}_{4} \mathrm{MgPO}_{4} \cdot 6 \mathrm{H}_{2} \mathrm{O}$. They assumed that the physical presence of the bacteria was also necessary. The production of this compound using both live and dead cells, as well as with and without bacterial exopolymers, indicated that $M$. xanthus cells may act as, or supply, heterogeneous nuclei for its synthesis and crystallization, when appropriate medium and a bacterial culture of suitable age were chosen. ${ }^{30,33}$

The formation of this product by Azotobacter vinelandii in a chemical medium was described by Rivadeneyra et al. ${ }^{34}$ Its formation by Aeromonas, Alcaligenes, Micrococcus, Murraya, and Plesiomonas was described by Rivadeneyra et $_{\text {al. }}{ }^{35}$

Rivadeneyra et al. ${ }^{36}$ working with different strains of Pseudomonas and Azotobacter, also found that, depending on culture age, heatkilled cells trigger the precipitation of $\mathrm{NH}_{4} \mathrm{MgPO}_{4} \bullet 6 \mathrm{H}_{2} \mathrm{O}$. Dead cells and cell debris may contribute to the formation of deposits of this product in nature. Crystallization of $\mathrm{NH}_{4} \mathrm{MgPO}_{4} \cdot 6 \mathrm{H}_{2} \mathrm{O}$ in the presence of very different bacterial genera has been previously reported. ${ }^{35}$ Indeed, Myxococcus, Pseudomonas and Azotobacter were found to produce this compound, which could indicate that this was a widespread phenomenon. It is noteworthy that social behavior, morphogenesis and differentiation of myxobacteria involved a phase in which $80-90 \%$ of the cells undergo lysis. This contributes to the concentration of heterogeneous crystallization nuclei. Since myxobacteria are frequent inhabitants of soils, the hypothesis that they participate in $\mathrm{NH}_{4} \mathrm{MgPO}_{4} \cdot 6 \mathrm{H}_{2} \mathrm{O}$ precipitation in nature was an attractive notion. ${ }^{30}$ Gonzalez-Muñoz et al ${ }^{37}$ found that $M$. xanthus membranes (total membrane fraction: inner and outer membranes) supply heterogeneous nuclei in the production of $\mathrm{NH}_{4} \mathrm{MgPO}_{4} \cdot 6 \mathrm{H}_{2} \mathrm{O}$. While some authors have found that each bacterial species generates only a very narrow range of crystal morphologies (Perez-Garcia et al. ${ }^{26}$ others found that $M$. xanthus and M. coralloides generated a wide range of crystal morphologies. ${ }^{30}$

A strain of Bacillus pumilus, isolated from the soil-borne fungal sclerotia produced crystals of the mineral $\mathrm{NH}_{4} \mathrm{MgPO}_{4} \bullet 6 \mathrm{H}_{2} \mathrm{O}$ on nutrient agar and a yeast extract agar containing magnesium sulphate and potassium phosphate. Crystals were macroscopically observed after 6-20 days of bacterial growth and reached a maximum size of $3 \times 0.5 \mathrm{~mm}$ on the plates. These findings support the hypothesis that bacteria were involved in the biogenic formation of this compound in nature. ${ }^{38}$

Proteus mirabilis affects the growth morphology and size of $\mathrm{NH}_{4} \mathrm{MgPO}_{4} \cdot 6 \mathrm{H}_{2} \mathrm{O}$ in artificial urine. ${ }^{39}$ The synthesis of $\mathrm{NH}_{4} \mathrm{MgPO}_{4} \bullet 6 \mathrm{H}_{2} \mathrm{O}$ crystals was promoted by Proteus mirabilis in the presence of urea and ammonium carbonate. The particles produced with bacteria are larger than those formed in the absence of bacteria. The mechanistic study suggested that biomolecules formed by bacteria may act as templates to the initiation of nucleation of crystal, followed by crystal growth and aggregation..$^{40}$

Proteus mirabilis in an artificial medium was also used for the preparation of $\mathrm{NH}_{4} \mathrm{MgPO}_{4} \cdot 6 \mathrm{H}_{2} \mathrm{O}$. ${ }^{41}$ The process was initiated by the addition of seed crystals (Figure 1a) to the reaction mixture containing the biomolecules and/or protein molecules from the bacteria. They probably adsorbed to certain crystal surfaces.

After some time, they grew to form crystallites. The protein and/ or other biomolecules of the bacterium may bind to (020) facets and induce flake formation. The flakes may self-assemble into spherical structures by inducement of biomolecules/ proteins (Figure 1b). At longer time, further growth led to the formation of particle aggregates 
of polygonal flakes having spherical morphology (Figure 1c). After further aging, polyhedrons formed, probably as a result of growth of crystal faces of the crystals via an Ostwald mechanism. ${ }^{41}$

Figure 1d shows the SDS-PAGE profile of the extracellular proteins produced by $P$. mirabilis. A distribution of protein with molecular weights ranging from 30 to $85 \mathrm{kDa}$ was observed. The zeta potential of aqueous medium of $P$. mirabilis was about $-57 \mathrm{mV}$, suggesting that the extracellular proteins generated by the bacteria were negatively charged. Therefore, the bacteria were able to bind $\mathrm{Mg}^{2+}$ by electrostatic attraction, providing nucleation sites for $\mathrm{NH}_{4} \mathrm{MgPO}_{4} 6 \mathrm{H}_{2} \mathrm{O}$ crystallization.

Metallophilic bacterium Enterobacter sp. EMB19 produced homogeneous crystals of $\mathrm{NH}_{4} \mathrm{MgPO}_{4} \cdot 6 \mathrm{H}_{2} \mathrm{O}$ in the mineralization of organic phosphorus. Interaction with cell free supernatant supplemented with $\mathrm{MgSO}_{4}$, resulted in $\mathrm{NH}_{4} \mathrm{MgPO}_{4} \bullet 6 \mathrm{H}_{2} \mathrm{O}$ crystallization after incubation. This is proof that the molecules responsible for this process were actually present in the supernatant and were probably secreted by the bacterial cells during their metabolism. This seems to confirm that proteins in the medium external to the cells were involved in the nucleation. The authors suggested that the coordination between proteins and $\mathrm{Mg}^{2+}$ and the subsequent interaction with ammonium ions could be an important driving force for the forming of $\mathrm{NH}_{4} \mathrm{MgPO}_{4} \bullet 6 \mathrm{H}_{2} \mathrm{O}$. A schematic representation of the compound produced by Enterobacter sp. EMB19 cells is shown in Figure 2.

It was suggested that the Enterobacter sp. EMB19 cells were producing the biomolecules, probably proteins, during bacteria growth. The authors suggested that these molecules probably were creating an appropriate local environment (e.g. super saturation), and in addition acting as a template for the nucleation and stereochemical arrangements of the $\mathrm{NH}_{4} \mathrm{MgPO}_{4} \cdot 6 \mathrm{H}_{2} \mathrm{O}$ crystals. ${ }^{42}$

The production of $\mathrm{NH}_{4} \mathrm{MgPO}_{4} \cdot 6 \mathrm{H}_{2} \mathrm{O}$ by removal of phosphates from supernatant liquors of anaerobic sludge digestion (anaerobic mesophilic bacteria) was reported by Battistoni et al. ${ }^{43}$ This compound was also produced by using epimastigotes of Trypanosoma cruzi. ${ }^{44}$ The Trypanosoma consumes glucose rapidly from the medium while the $\mathrm{pH}$ decreases from 6.3 to 5.5, since acids are generated (e.g. succinic), and then produces high levels of ammonium hydroxide, probably as a result of protein metabolism, thereby raising the $\mathrm{pH}$ to 7 and leading to $\mathrm{NH}_{4} \mathrm{MgPO}_{4} \cdot 6 \mathrm{H}_{2} \mathrm{O}$ precipitation.

The main application of this compound is as fertilizer, however, a study showed that $\mathrm{NH}_{4} \mathrm{MgPO}_{4} \cdot 6 \mathrm{H}_{2} \mathrm{O}$ treatment is also viable for nutrient management of algal cultivation on sewage wastewaters which do not have suitable nutrient profiles. ${ }^{45}$

$\mathrm{NH}_{4} \mathrm{MgPO}_{4} \cdot 6 \mathrm{H}_{2} \mathrm{O}$ was successfully applied in potted maize cultivation with a height, circumference of the stalk plant and growth

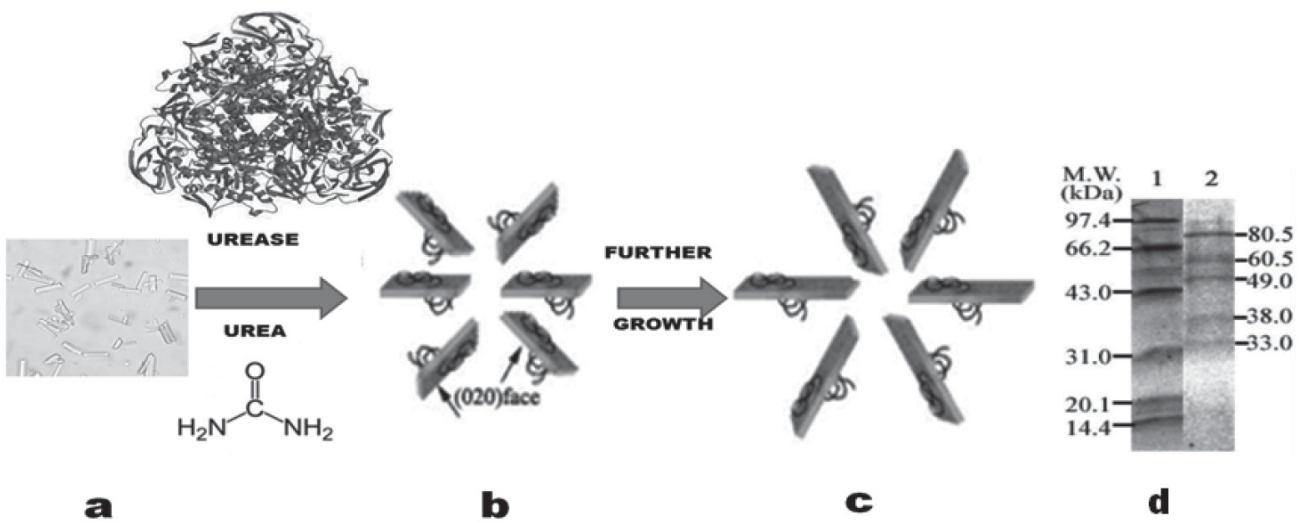

Figure 1. Schematic representation of the formation process of $\mathrm{NH}_{4} \mathrm{MgPO}_{4} \cdot 6 \mathrm{H}_{2} \mathrm{O}$ superstructure constructed from small flakes: a) Seeds crystals; $b$ ) Selfassembly into spherical superstructures; c) Aggregated particles; d) SDS-PAGE data showing the proteins generated by Proteus mirabilis. Lane 1: standard protein m.w. markers in kDa. Lane 2: protein bands in P. mirabilis secretions (modified from Chen et al., 2010) ${ }^{41}$

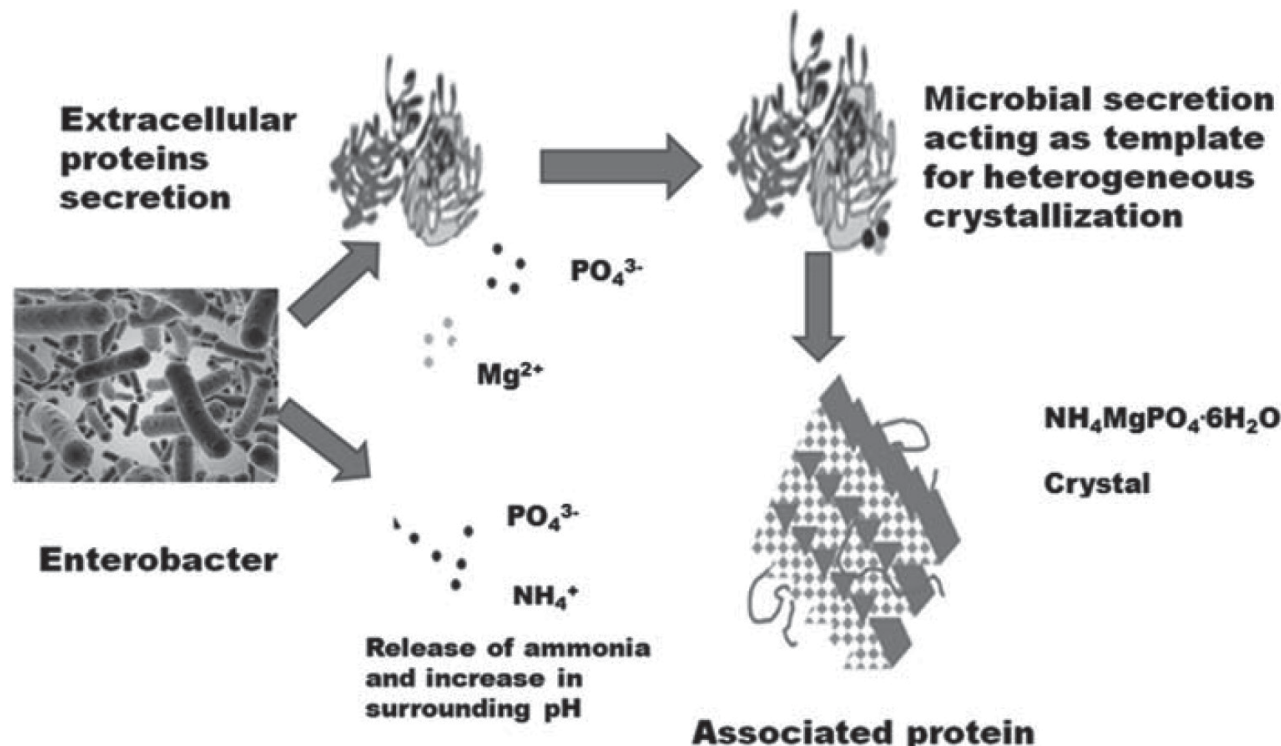

Figure 2. Scheme representing the probable mechanism of $\mathrm{NH}_{4} \mathrm{MgPO}_{4} \cdot 6 \mathrm{H}_{2} \mathrm{O}$ formation by Enterobacter sp EMB19 cells (modified from Sinha et al., 2014 ) ${ }^{42}$ 
similar to that on fused super phosphate (FSP)-urea fertilizers. However, leaf area and biomass yield were significantly higher on $\mathrm{NH}_{4} \mathrm{MgPO}_{4} \cdot 6 \mathrm{H}_{2} \mathrm{O}$ - treated than on FSP-urea-treated soils. Moreover, the rate of $\mathrm{N}_{2} \mathrm{O}$ emission was one third from $\mathrm{NH}_{4} \mathrm{MgPO}_{4} \cdot 6 \mathrm{H}_{2} \mathrm{O}$-treated soil compared to that from FSP-urea treated soil. The application of $\mathrm{NH}_{4} \mathrm{MgPO}_{4} \cdot 6 \mathrm{H}_{2} \mathrm{O}$ could also be useful in the reduction of greenhouse gas from crop cultivation. ${ }^{46}$

\section{$\mathrm{MgHPO}_{4} \bullet 3 \mathrm{H}_{2} \mathrm{O},\left(\mathrm{NH}_{4}\right)_{2} \mathrm{Mg}\left(\mathrm{HPO}_{4}\right)_{2} \bullet 4 \mathrm{H}_{2} \mathrm{O}$}

Other phosphates produced by myxobacteria, $\mathrm{MgHPO}_{4} \cdot 3 \mathrm{H}_{2} \mathrm{O}$ and $\left(\mathrm{NH}_{4}\right)_{2} \mathrm{Mg}\left(\mathrm{HPO}_{4}\right)_{2} \bullet 4 \mathrm{H}_{2} \mathrm{O}$, were reported by Gonzalez-Muñoz et $a l .{ }^{47}$ and by Jimenez-Lopez et al. ${ }^{48}$ They are of interest because they also appear in kidney calculi. ${ }^{49}$ These minerals, which have been considered syngenetic ${ }^{50}$ with $\mathrm{NH}_{4} \mathrm{MgPO}_{4} \cdot 6 \mathrm{H}_{2} \mathrm{O}$, were also produced by $M$. coralloides $\mathrm{D}$ as minor mineral phases when $\mathrm{NH}_{4} \mathrm{MgPO}_{4} \bullet 6 \mathrm{H}_{2} \mathrm{O}$ was found in certain liquid cultures under static conditions. These compounds normally serve as magnesium phosphate cements. ${ }^{47}$ Radio-opaque $\left(\mathrm{NH}_{4}\right)_{2} \mathrm{Mg}\left(\mathrm{HPO}_{4}\right)_{2} \bullet 4 \mathrm{H}_{2} \mathrm{O}$ has been developed for endodontic applications because of its excellent characteristics in canal-sealing, such as easy injectability, short setting time and high early compressive strength. ${ }^{51}$ Furthermore, it exhibited excellent sealing efficiency compared to commercial mineral trioxide aggregate (MTA) cements. ${ }^{51}$

\section{$\left(\mathrm{NH}_{4}\right)_{2} \mathrm{Mg}_{3}\left(\mathrm{HPO}_{4}\right)_{4} \cdot 8 \mathrm{H}_{2} \mathrm{O}$}

$\left(\mathrm{NH}_{4}\right)_{2} \mathrm{Mg}_{3}\left(\mathrm{HPO}_{4}\right)_{4} \bullet 8 \mathrm{H}_{2} \mathrm{O}$ was found in minerals derived from the interaction of bat urine, excrements and calcarium (guano). Enterobacteriaceae are the most common microorganism in the bat guano (30-45 x 107 UFC/g). Application of this compound as filler for smoking articles (e.g. cigarettes supports, filters, etc.) was published as a patent. ${ }^{52}$

\section{$\mathrm{Mg}_{3}\left(\mathrm{PO}_{4}\right)_{2} \bullet 8 \mathrm{H}_{2} \mathrm{O}$}

A number of bacterial strains exhibit the ability to precipitate spherulites of phosphate compounds, such as $\mathrm{Mg}_{3}\left(\mathrm{PO}_{4}\right)_{2} \bullet 8 \mathrm{H}_{2} \mathrm{O}$. This is of interest because this mineral is rarely found in nature. It is generally described as being associated with microbial activity in special habitats containing high concentrations of organic matter (e.g. Acinetobacter $s p$ ). ${ }^{53-55}$

Addition of $\mathrm{Mg}_{3}\left(\mathrm{PO}_{4}\right)_{2} \bullet 8 \mathrm{H}_{2} \mathrm{O}$ to a complex medium with or without ammonium ion stimulated leucomycin production by Streptomyces kitasatoensis. High concentration of ammonium ions in high concentrations inhibited leucomycin production. ${ }^{56}$

\section{$\mathrm{Mg}_{3}\left(\mathrm{PO}_{4}\right)_{2} \bullet 22 \mathrm{H}_{2} \mathrm{O}$ and $\mathrm{MgKPO}_{4} \bullet 6 \mathrm{H}_{2} \mathrm{O}$}

Microbiological formation by unknown bacteria of a mixture of $\mathrm{Mg}_{3}\left(\mathrm{PO}_{4}\right)_{2} \cdot 22 \mathrm{H}_{2} \mathrm{O}$ and $\mathrm{MgKPO}_{4} \cdot 6 \mathrm{H}_{2} \mathrm{O}$ has also been reported. The authors suggested that in the culture medium, the phosphatemineralizing bacteria produced alkaline phosphatase, which constantly decomposed its substrate enzymatically, producing $\mathrm{PO}_{4}{ }^{3-}$ or $\mathrm{HPO}_{4}{ }^{2-}$. Probably the concentration of those ions, increased during continuous depositions of substrate in a cyclic process. ${ }^{57}$ Phosphate anions were formed when $\mathrm{pH}$ was adjusted to 10.5 . Water-soluble negatively charged organic products (or proteins) on the surface of bacterial cells constantly chelate $\mathrm{Mg}^{2+}$ causing a local increase in phosphate concentration and a reaction of $\mathrm{Mg}^{2+}$ with this phosphate until the concentration of the crystal precursor has increased sufficiently for nucleation and precipitation of the magnesium phosphates particles. ${ }^{57}$

\section{$\mathrm{Mg}_{3}\left(\mathrm{PO}_{4}\right)_{2} \cdot 5 \mathrm{H}_{2} \mathrm{O}, \mathrm{MgHPO}_{4} \cdot 1.2 \mathrm{H}_{2} \mathrm{O}$}

SEM study of a deposit of a mixture of $\mathrm{MgHPO}_{4} \bullet 1.2 \mathrm{H}_{2} \mathrm{O}$ and $\mathrm{Mg}_{3}\left(\mathrm{PO}_{4}\right)_{2} \cdot 5 \mathrm{H}_{2} \mathrm{O}$ by Bacillus subtilis revealed the presence of clusters and honeycomb shapes, whose sizes were in the range of 1-3 $\mu \mathrm{m} .{ }^{58}$

Magnesium phosphates, such as, $\mathrm{Mg}_{3}\left(\mathrm{PO}_{4}\right)_{2}, \mathrm{MgHPO}_{4}$, and $\mathrm{Mg}\left(\mathrm{H}_{2} \mathrm{PO}_{4}\right)_{2}$ were used for promoting $\mathrm{F}$ actin formation in the manufacture of a medicine for the treatment of a disease of the respiratory tract. A patent describes a method to improve the performance of DNA degrading proteins (DNAse) in the treatment of pulmonary disease such as cystic fibrosis, which is characterized by the presence of highly viscous pulmonary secretions in the lung. A major drawback in the DNAse treatment of pulmonary diseases was its binding to monomeric actin (G actin) and its subsequent inactivation. The negative affect of actin monomers on the activity of DNAse was countered by shifting the equilibrium of actin depolymerization towards the polymeric, filamentous state (F actin). This shift was promoted by ions such as that magnesium or potassium associated to phosphates, and was brought about in a combination with DNAse. ${ }^{59}$

\section{$\mathrm{Mg}_{2} \mathrm{Na}\left(\mathrm{NH}_{4}\right)\left(\mathrm{PO}_{4}\right)_{2} \cdot 14 \mathrm{H}_{2} \mathrm{O}$}

A biogenic phosphate, $\mathrm{Mg}_{2} \mathrm{Na}\left(\mathrm{NH}_{4}\right)\left(\mathrm{PO}_{4}\right)_{2} \bullet 14 \mathrm{H}_{2} \mathrm{O}$, was found in bacterial cultures of a Virgibacillus sp. strain. The culture was grown aerobically on plates at $25{ }^{\circ} \mathrm{C}$ and checked for formation of the product for up to 60 days. ${ }^{60}$

\section{$\mathrm{Mg}_{2}\left(\mathrm{NH}_{4}\right)_{3} \mathrm{H}_{5}\left(\mathrm{PO}_{4}\right)_{4} \cdot 10 \mathrm{H}_{2} \mathrm{O}$}

$\mathrm{Mg}_{2}\left(\mathrm{NH}_{4}\right)_{3} \mathrm{H}_{5}\left(\mathrm{PO}_{4}\right)_{4} \bullet 10 \mathrm{H}_{2} \mathrm{O}$ was precipitated by Azospirillum brasilense (strain $\mathrm{Sp} 245$ ) in a synthetic phosphate medium. The product was studied microscopically and physicochemically. ${ }^{61}$

\section{$\mathrm{C}_{18} \mathrm{H}_{35} \mathrm{Mg}_{2} \mathrm{NO}_{21} \mathrm{P}_{5}$}

An immunomodulator produced by fungi (biogenic) with a high ratio of phosphate to magnesium called P-MAPA (a polymeric aggregate of protein magnesium ammonium phospholinoleate and palmitoleate anhydride) was reported 27 years ago. ${ }^{62-65}$ The P-MAPA structure, $\mathrm{C}_{18} \mathrm{H}_{35} \mathrm{Mg}_{2} \mathrm{NO}_{21} \mathrm{P}_{5}$ (unitary cell) was produced by fungal cultures such as Penicillum sp. ${ }^{62}$ or by Aspergillus oryzae ${ }^{65}$ with a phosphate/Mg ratio of 2.2 .

The P-MAPA structure contains a protein reported to have a size of $\sim 10 \mathrm{kDa}(0.5 \% \mathrm{~m} / \mathrm{m})$ and lipids (linoleate and palmitoleate, $11.6 \%$ $\mathrm{m} / \mathrm{m}) .{ }^{62}$ After extracting the protein in acid medium, an analysis by a different method, which is described below, showed it to have a size of $\sim 15 \mathrm{kDa}$ and also $\sim 20 \mathrm{kDa}$. But when hydrolyzed with phospholipase (LPA2), the protein appeared to have a size of $12 \mathrm{kDa}$ (Figure 3) ${ }^{66}$

A revised structure of the protein had the lipid and protein associated with the phosphate as lipoprotein. The hypothetical structure is shown in Figure 4.

P-MAPA was neither cytotoxic or genotoxic in cultured V79 Chinese hamster fibroblast cells nor in human lymphocytes. P-MAPA was also non-toxic to mice, dogs or monkeys. ${ }^{63,67,68}$ This is important since hematotoxicity in the recipient is observed with the majority of cancer chemotherapeutic agents in routine use, thereby limiting the application in optimal dose schedules.

Since in vitro, no cell growth-inhibiting activity was found against 53 tumor cell lines, ${ }^{68}$ it was suggested at that probably other factors could be involved immunologically. ${ }^{69}$

P-MAPA exhibits anti-malaria, ${ }^{66,70,71}$ antiviral activity ${ }^{62,72-75}$ and antibacterial activity. ${ }^{73,75}$ This compound exhibited also a significant in vivo antitumoral activity. ${ }^{63-65,68,69,72,76-78,81-85}$ 


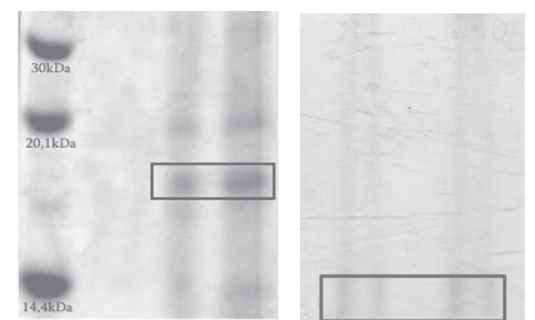

$\sim 15 \mathrm{kDa}$

$\sim 12 \mathrm{kDa}$

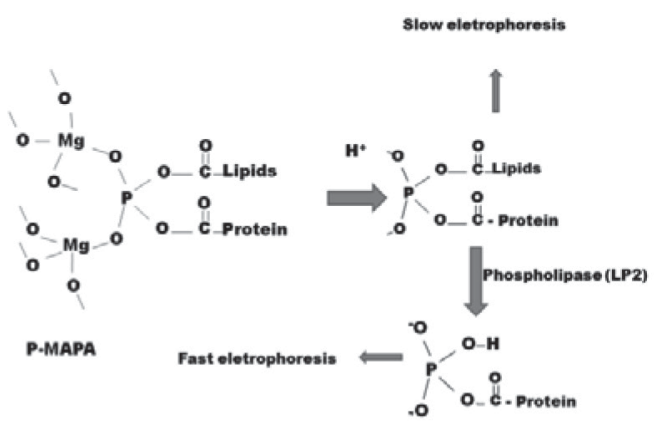

C

Figure 3. Protein electrophoresis of P-MAPA: A) Protein extracted in acid medium. B) Protein after hydrolysis with phospholipase (PLA2). C) Possible appearance of protein structure after phospholipase hydrolysis

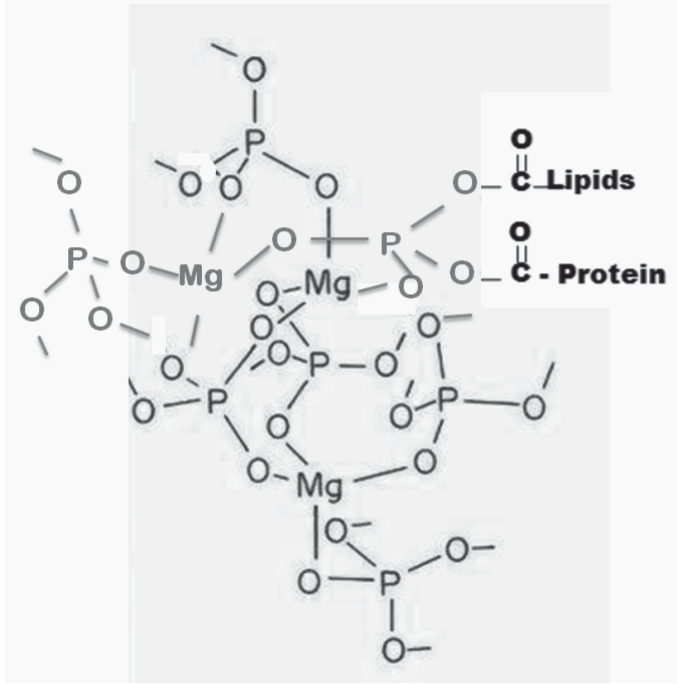

Figure 4. Possible structure of the polymeric aggregate of protein magnesium ammonium phosphate and palmitoleate anhydride (modified from Santos et al., 2009; Durán and Fávaro, 2016) $)^{6,95}$

The therapeutic action of P-MAPA was evaluated against malaria in mice infected with Plasmodium chabaudi. Complete inhibition of the disease agent was observed with a dose of $100 \mathrm{mg} \mathrm{kg}^{-1}$ over 6 days. In a control group, $50 \%$ of the test animals died. In a group of mice treated with dose of $5 \mathrm{mg} / \mathrm{kg}, 90 \%$ survival was observed during 9 days, compared to $60 \%$ survival in the control group. ${ }^{71,73}$

It was previously demonstrated that P-MAPA exhibited antiviral activities against Stomatitis vesicular virus, Poliovirus 3, Herpes virus type 1, and Adenovirus type $5 .{ }^{63}$ An i.p. dose administered 24 $\mathrm{h}$ post infectious challenge (100 $\mathrm{mg} \mathrm{kg}^{-1}$ of P-MAPA) was effective in preventing death due to infection with Punta Toro virus. This treatment also reduced systemic viral burden and discoloration of the liver assayed on 3 th day of infection. These data appeared to indicate at that time that the immunotherapy with P-MAPA was non-specific. ${ }^{73}$

P-MAPA toll-like receptors (TLRs) 2- and 4- stimulating properties were tested in vitro or in vivo against Mycobacterium tuberculosis (Erdman strain). In vivo P-MAPA alone demonstrated an important effect against this strain (i.e., at $5 \mathrm{mg} \mathrm{kg}^{-1}$ ). However, P-MAPA showed no direct antibacterial activity in vitro against Mycobacterium tuberculosis (H37Rv). These data suggested that P-MAPA exhibited an immunotherapeutic effect against tuberculosis only in vivo. ${ }^{73,74,86}$

Inhibition of tumor growth (e.g., marked inhibition) and concomitant extension of the host's life span after P-MAPA treatment of animals bearing transplantable lymphosarcoma-180, plasmacytoma SP-2/O/ Ag14, Ehrlich solid carcinoma, Walker 256 tumor and spontaneous mammary carcinoma-SP-1 has been observed. ${ }^{68,77}$

Myelosuppression has been observed simultaneously with increased numbers of spleen CFU-GM in tumor-bearing mice. However, P-MAPA treatment of these animals $\left(0.5-10 \mathrm{mg} \mathrm{kg}^{-1}\right)$ stimulated myelopoiesis (marrow) in a dose-dependent manner which also reduced spleen colony formation. Total and differential marrow cell counts did not change. A dose of $5.0 \mathrm{mg} / \mathrm{kg}$ P-MAPA administered prior or after tumor inoculation, was optimal for tumorbearing mice. This dose also stimulated myelopoiesis in normal mice. P-MAPA efficiently enhanced survival and simultaneously reduced tumor growth in the peritoneal cavity. ${ }^{64}$

Ehrlich ascites tumor (EAT) exerts its action by diminishing mitogen induced expansion of cell populations in spleen and total NK activity. This was followed by striking spleen enlargement, and a significant increase in total cell counts. Furthermore, an important enhancement in IL-10 levels, concurrent with an important decrease in IL-2 was observed. However, production of IL-4 and interferon- $\gamma$ (IFN- $\gamma$ ) was not affected. Treatment of mice with P-MAPA (5 mg kg-1) for 7 days induced spleen cell proliferation, NK cell activity and IL-2 production were indifferent to tumor outgrowth. Furthermore, P-MAPA treatment significantly enhanced IFN- $\gamma$ levels and reduced IL-10 production compared to that in EAT mice. Splenomegaly reduction of $35 \%$ with a normal number of nucleated cells was found..$^{65,83}$

A few years ago, P-MAPA appeared as a potential candidate for intravesical therapy for non-muscle invasive bladder cancer (NMIBC). This immunomodulator was found to be important in the treatment of these types of urinary bladder cancer, ${ }^{76,82,84,86,87}$ as well as in the prostate cancer ${ }^{88}$ and of pancreatic cancer. ${ }^{89}$

The most recent results with respect to NMIBC demonstrated that the immune system by BCG activation (MyD88-dependent pathway) leads to an increased inflammatory cytokines production. By contrast, P-MAPA intravesical immunotherapy resulted in a distinct activation of TLRs 2 and 4-mediated innate immune system, leading to increased TRIF-dependent pathway, an interferon signaling pathway, that is extremely effective in NMIBC treatment. TRIF-dependent pathway activation induced by P-MAPA resulted in an increase of iNOS protein levels, leading to apoptosis and histopathological recovery. Besides, P-MAPA immunotheraly induced an increase in wild-type p53 protein levels. The wild-type p53 protein level production was important to NO-induced apoptosis and also to the BAX upregulation. In addition, induction by P-MAPA of an interferon signaling pathway simultaneously with increased p53 protein levels resulted in an important antitumor effect, not only by suppressing 
abnormal proliferation, but also by preventing continuous tumor mass growth by suppression of angiogenesis, observable by a decrease in vascular endothelial growth factor (VEGF) and an increase in endostatin protein levels (Figure 5). ${ }^{84}$

Another important mechanism of action of P-MAPA intravesical immunotherapy in NMIBC treatment is regulation of steroid hormone receptors (androgen and estrogen receptors), as well as the association of these receptors with the immune system (toll-like receptors). Garcia et $a l .{ }^{85}$ first demonstrated the control activity of androgen receptor (AR) and estrogen receptors alpha $(\mathrm{ER} \alpha)$ and beta $(E R \beta)$ through Siah-2 ubiquitin ligase and co-repressor N-CoR in the NMIBC. These authors demonstrated that increased AR levels may play a critical role in urothelial carcinogenesis, suggesting that this receptor was a potential therapeutic target for NMIBC. The AR signals were related to Siah-2 and N-CoR levels (Figure 5). Both increased Siah-2 and decreased N-CoR signals led to a decrease in TLRs 2 and 4 levels, resulting in the escape of urothelial cancer cells from immune system attack (Figure 5). P-MAPA immunotherapy administered alone and/ or in combination with AR blockade (e.g., flutamide) was more effective in recovery of the immunosuppressive tumor immune microenvironment than was BCG treatment, as a result of the following: decreased levels of Siah-2 and AR, increased levels of $\mathrm{N}-\mathrm{CoR}, \mathrm{ER} \alpha$ and $\mathrm{ER} \beta$, and activation of the interferon signaling pathway (Figure 5).

Apolinario et al. ${ }^{88}$ characterized and compared the morphological and molecular effects of antiangiogenic therapy combined with P-MAPA immunotherapy in the treatment of chemically induced prostatic lesions in rats and sought to establish possible mechanisms of action of these therapies involving inducing and repairer factors of cell injury, sex hormone steroid receptors, angiogenesis and antioxidant enzymes. After induction, the animals were treated with $5 \mathrm{mg} / \mathrm{kg}$ of P-MAPA and an anti-angiogenic drug (TNP470[(O-(chloroacetylcarbamoyl)fumagillol]) $\left(15 \mathrm{mg} \mathrm{kg}^{-1}\right)$. Results demonstrated that chemical induction of prostatic lesions was effective in the promotion of premalignant (intraepithelial neoplasia (PIN) and proliferative inflammatory atrophy (PIA)) and malignant (adenocarcinoma) lesions in Fischer 344 strain, making it a suitable model for trials of efficacy and toxicity of new therapeutic perspectives against prostate cancer. P-MAPA and TNP470's effects were different on premalignant and malignant lesions and affected steroid hormone receptor levels and tissue repair, oxidative stress and angiogenesis pathways. P-MAPA demonstrated significant antitumoral activity against intermediate grade and high-grade adenocarcinomas and it was also effective against proliferative inflammatory atrophy (PIA). The association of P-MAPA with TNP470 was the best therapeutic approach against PIN and PIA, but it was less effective against prostate adenocarcinoma than P-MAPA alone.

The pancreatic cancer inducer 7,12-dimethylbenz[a]antracene (DMBA) crystals were implanted in the head of the pancreas of rats. It was compared to Gemcitabine $\left(10 \mathrm{mg} \mathrm{kg}^{-1}\right)$ and 5 P-MAPA $(5 \mathrm{mg} / \mathrm{kg}$ ). The histopathology results showed the effectiveness of DMBA in pancreatic cancer in the rats, as well as progressive tissue repair, particularly in the presence of P-MAPA, during therapeutic treatment. ${ }^{89}$

It interesting that P-MAPA was also observed as a nanosized structure upon nanoprecipitation in dimethyl sulfoxide and water, ${ }^{70,73,79}$ by high pressure homogenization and by ultrasound in the presence of Pluronic F68 and coating with chitosan..$^{75,80,81,90-95}$ Nanonization is a top-down process, i.e. from micro- to nano-size. The starting material was P-MAPA crystals (micro structured). Each different process showed slight morphological differences (Figure 6).

Magnesium and ammonium associated to phosphate appeared important in cancer treatment, either in a macro- or nano-structured form.

The effect of P-MAPA on canine viruses, especially parvovirus and distemper virus ${ }^{62}$ and on Leishmaniasis ${ }^{96-109}$ was also studied, as it was non toxic to normal tufted Capuchine monkeys (Cebus apella) ${ }^{67}$

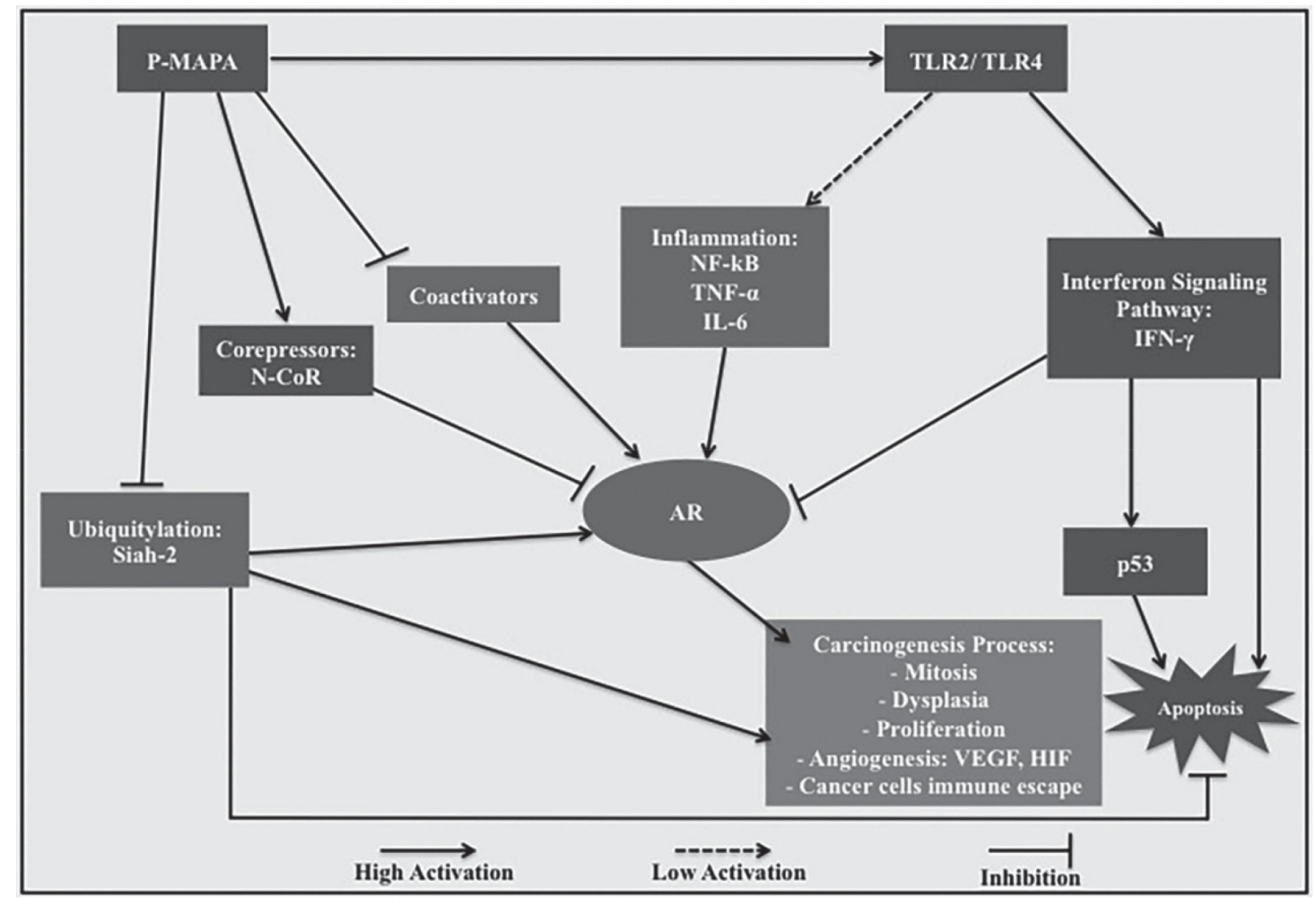

Figure 5. Schematic representation of the hypothetical mechanism of action of P-MAPA involving steroid hormone receptors and co-activators (Siah-2) and co-repressors (N-CoR); TLRs signaling pathway and 553 (created by W.J. Fávaro) 


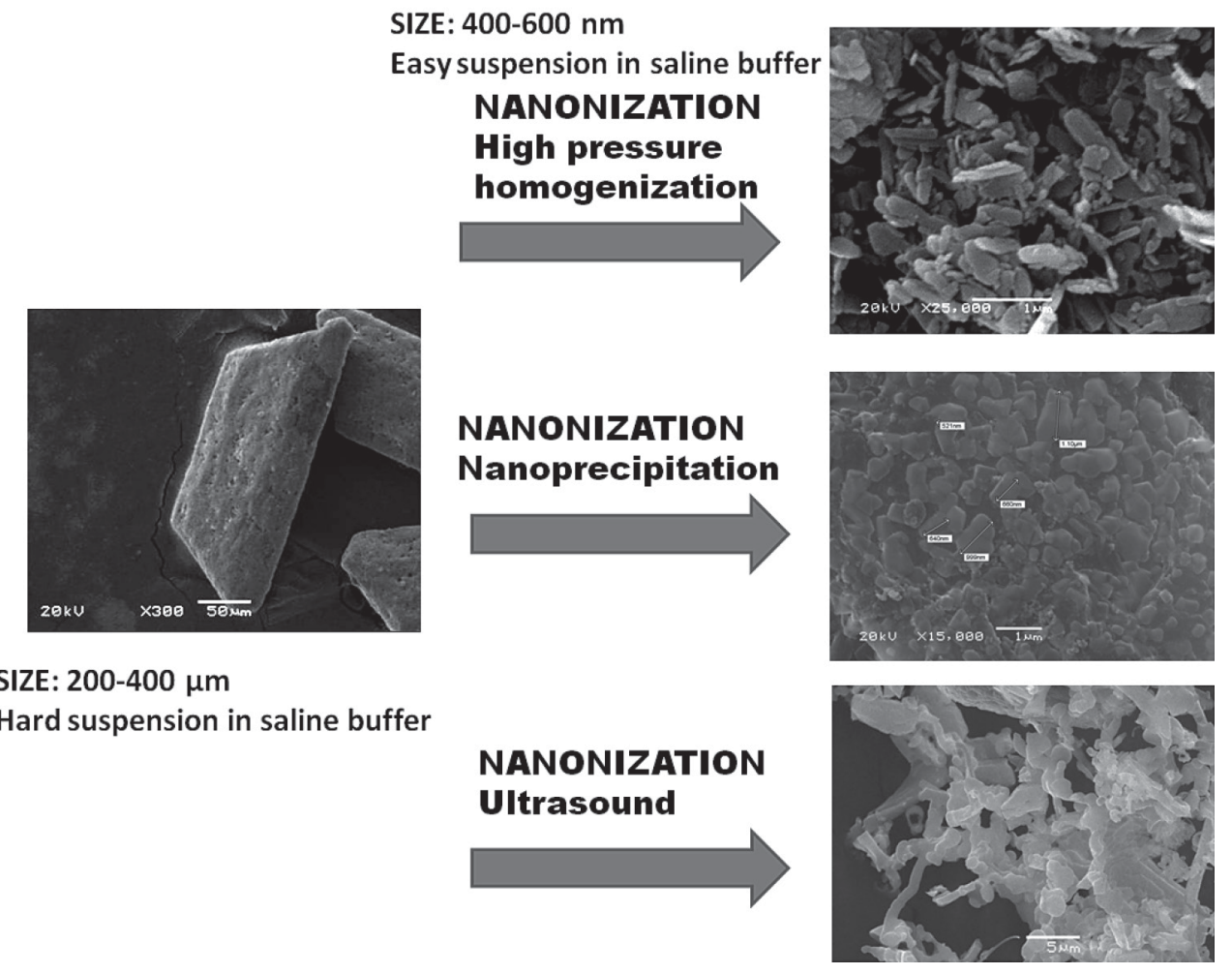

Figure 6. Scheme of nanonization (top-down processes) of P-MAPA

Virus-infected dogs were treated with P-MAPA by daily intramuscular injection ( $20 \mathrm{mg} / 10-15 \mathrm{~kg}$ body weight) for periods of 3-6 days in the case of parvovirus, and distemper infection. Clinical signs that were evaluated included conjunctivitis, rhinitis, cough, vomiting, diarrhea, central nervous system signs, and hyperkeratosis of foot pads, tonsillitis, anorexia, hydration status, purulent dermatitis and lymph node size. Sera of a few animals were analyzed with rabbit anti-dog IgG conjugated with horseradish peroxidase. Canine antiCDV reference serum was used as the positive control in all tests. Over $95 \%$ of the dogs recovered after this treatment. ${ }^{63}$

In groups exhibiting leishmaniasis, treatment with P-MAPA enhanced the clinical signs and reduced the parasite burden in the skin. Supernatant from cultures of peripheral blood mononuclear cells showed a decrease in IL-10 levels and in IL-2 and IFN-(gamma) increment An increment in CD8+ T cells in peripheral blood was also observed. Beside this, the in vitro leishmanicidal action of P-MAPA investigated using 3-(4,5-dimethylthiazol-2-yl)-2,5diphenyltetrazolium bromide (MTT) demonstrated no leishmanicidal activity. These observations suggested that P-MAPA has potential as an immunotherapeutic drug in canine visceral leishmaniasis, but not in vitro, since it assists in reestablishing partial immunocompetence of infected dogs. ${ }^{97}$

Several parameters in healthy and Leishmania-infected dogs treated with P-MAPA were studied. Macrophages in culture of peripheral blood mononuclear cell (PBMC) were isolated. They were tested in culture with different concentrations of P-MAPA (20, 100 and $200 \mu \mathrm{g} \mathrm{mL}^{-1}$ ) at $37{ }^{\circ} \mathrm{C}$ with $5 \% \mathrm{CO}_{2}$ in a humid environment. ${ }^{104}$ Leishmania-infected dogs exhibited a decrease in TLR2 in macrophages compared to healthy dogs. Reactive oxygen species (ROS) were large in PBMCs from Leishmania spp.-infected dogs compared to healthy dogs and P-MAPA. Nitric oxide generation was increased in macrophage culture supernatant stimulated by P-MAPA in either healthy dogs or Leishmania spp. infected dogs. Treatment of macrophages from healthy dogs with P-MAPA, induced p38 MAPK and IKK phosphorylation, indicating signal transduction by this pathway. All these data suggested that P-MAPA has potential as a therapeutic drug in the canine visceral leishmaniasis treatment. ${ }^{104}$

The effects of daily immunomodulatory use on blood parameters and organs of Cebus apella (tufted capuchin monkey) were studied for a period of 30 days. In this study, animals received i.m. injections at three different concentrations. The study found no toxic changes in hematological parameters and organs of these animals with the 3 dosages of P-MAPA. There was a reduction of the levels of cholesterol and triglycerides but there were no changes in glucose levels, total protein, albumin and aspartate aminotransferase (AST) ${ }^{67}$

\section{FINAL REMARKS}

The biogenic processes examined in this review are very important in nature. The environmental importance, that it has been suggested is that these molecules are phosphates reserve for living beings. Magnesium phosphates having different structures are available for different reactions and uses. Important aspect is that magnesium phosphates are sources of magnesium. In the case of magnesium deficiency disease, phosphate-containing pro-drugs liberates phosphate are widely used as sources of this element for a specific target. Also was clear from this review that magnesium has crucial functions in numerous biological processes and at different levels, such as cofactor in ATP, stabilizer of membranes, nucleic acid, and complex proteins, and as a molecular marker. Important function on cancer, on heart attack, diabetes and many others were reported. The biogenic magnesium phosphates are useful in several industrial utilization, such as in cement and fertilizer.

It is interesting that except for P-MAPA, no medical applications of biogenic magnesium phosphate derivatives were found in the literature. The development of P-MAPA was clearly the most important contribution by CEDECAB Farmabrasilis (Durán and Nunes, 1990). ${ }^{62}$ Many researchers have found medical applications for P-MAPA. In 2013, these discoveries resulted in the Reward for 
Technological Innovation in Oncology from Octavio Frias de Oliveira Award (ICESP). CEDECAB-Farmabrasilis, a non-governmental and non-profit research network and formed by scientist volunteers and many others devoted to investigation, research and development of novel medication and technologies on the premise that it will profit economically deprived populations and individuals suffering from neglected diseases (http://www.farmabrasilis.br).

\section{ACKNOWLEDGEMENT}

We acknowledge researchers who work voluntarily on the development of P-MAPA, such as, G.Z. Justo (UNIFESP), V.M.F. De Lima (UNESP), D.V. Tambourgi (Butantan), A. SouzaBrito (UNICAMP), L.M. Apolinario (UNICAMP), P.V. Garcia (UNICAMP), J.A. de Oliveira (UNESP), A. Hetem (UNESP), A.M. Macedo (UNESP), P.R. Botacin (UNESP), M. Mazzeto (Med. Vet. SP), D.B. Ciampi (UNICAMP), F.T.M. Costa (UNICAMP). L.Tasic (UNICAMP), M. Durán (UNICAMP), R. Pisani (UNICAMP), M. Haun (UNICAMP), M.L.S. Queiroz (UNICAMP), A.N. Vieira-Matos (UNICAMP) O. Rettori (UNICAMP), L.P. Da Silva (UNICAMP), M. Brocchi (UNICAMP), S. Bellucci (Centro Corsini), B.B. Gowen (Utah State University-USA), A.J. Lenaerts (Colorado State UniversityUSA), L. Vargas (Long Island Jewish Med. Center-USA), A.C.S. Lima (UNICAMP), A. Billis (UNICAMP), F.R.F. Seiva (UNESP), P.K. Böckelmann (UNICAMP), E.A.R. Socca (UNICAMP), Q.C. Dias (UNICAMP), A.B. Seabra (UFABC, SP), S. Tizziani (Med. Vet., SP), R. Chammas (ICESP, SP), and we appreciated for their contribution during 30 years of P-MAPA development.

Support from all the Brazilian Institution for P-MAPA development: Brazilian Network on Nanobiotechnology (CNPq)(Proc. 490799/20078), Brazilian Network on Nanotoxicology (CNPq/MCTI) (Proc. 552120/2011-1), INOMAT (CNPq)(Proc. 573644/2008-0), NanoBioss (MCTI)(Proc. 402280/2013-0), CNPq (Proc. 483755/20109, 490519/2011-3, 475211/2013-8), FAPESP: 97/01504-8, 99/060523-Prof. Justo UNICAMP, Campinas, SP, Brazil; 2009/50426-9- Prof. De Lima-UNESP-Araçatuba, SP, Brazil; 12/05306-8-Dr. TambourgiButantan-SP, Brazil; 15/00423-4, 16/03993-9- Prof. Chuffa-UNESPBotucatu, SP, Brazil; 13/10520-1, 13/11346-5, 13/10521-8, 15/20767-0, 16/07393-6- Dr. Garcia-UNICAMP, Campinas, SP, Brazil; 11/037741, 11/05726-4, 11/05919-7, 12/16880-7, 12/11002-1, 12/19741-8, 12/13585-4, 12/207062, 13/01600-1, 13/11082-8, 14/11866-1, 14/12047-4- Prof. Fávaro-UNICAMP, Campinas, SP, Brazil; 00/084221, 14/08549-4- Prof. Durán-UNICAMP, Campinas, SP, Brazil) and CAPES were also acknowledged.

We also thank CEDECAB-Farmabrasilis (Head Diretor, Sr. Iseu S. Nunes) for the constant incentive to our research on P-MAPA and we would like to thank Dr. Carlos H. Fioravanti for the journalistic support of P-MAPA development for several years.

We would also like to thank CitroSuco foi supporting our research.

\section{REFERENCES}

1. Guastaldi, A. C.; Aparecida, A. H.; Quim. Nova 2010, 33, 1352.

2. Domingos, J. B.; Longhinotti, E.; Machado, V. G.; Nome, F.; Quim. Nova, 2003, 26,745.

3. Kataki, S.; West, H.; Clarke, M.; Baruah, D. C.; Waste Manage. 2016, 49, 437.

4. Pantano, G.; Grosseli, G. M.; Mozeto, A. A.; Fadini, P. S.; Quim. Nova 2016, 39, 732 .

5. Del Rio, A. V.; Gomez, J. L. C.; Corral, A. M.; Technologies for the treatment and recovery of nutrients from industrial wastewater. IGI Global Press: Hershey, 2017.

6. Huttunen, K. M.; Raunio, H.; Rautio J.; Pharm. Rev. 2011, 63, 750.
7. Fang, X.; Wang, K.; Han, D.; He, X.; Wei, J.; Zhao, L.; Imam, M. U.; Ping, Z.; Li, Y.; Xu, Y.; Min, J.; Wang, F.; BMC Medicine 2016, 14, 210.

8. Tao, M-H.; Dai, Q.; Millen, A. E.; Nie, J.; Edge, S. B.; Trevisan, M.; Shields, P. G.; Freudenheim, J. L.; Am. J. Cancer Res. 2016, 6, 105.

9. Dai, Q.; Motley, S. S.; Smith Jr., J. A.; Concepcion, R.; Barocas, D.; Byerly, S.; Fowke, J. H.; PLoS One 2011, 6, e18237.

10. Brinkman, M. T.; Buntinx, F.; Kellen, E.; Dagnelie, P. C.; Van Dongen, M. C. J. M.; Muls, E.; Zeegers, M.P.; Cancer Causes Control 2011, 22, 469.

11. Castiglioni, S.; Maier, J. A.; Magnesium Res. 2011, 24, S92.

12. Folsom, A. R.; Hong, C-P.; Am. J. Epidemiol. 2006; 163, 232.

13. Larsson, S. C.; Bergkvist, L.; Wolk, A.; JAMA 2005, 293, 86.

14. Van den Brandt, P. A.; Smits, K. M.; Goldbohm, R. A.; Weijenberg, M. P.; Br. J. Cancer 2007, 96, 510.

15. Smirnov, A.; Suzina, N.; Chudinova, N.; Kulakovskaya, T.; Kulaev, I.; FEMS Microbiol. Ecol. 2005, 52, 129.

16. Kulakovskaya, T. V.; Vagabov, V. M.; Kulaev, I. S.; Process Biochem. 2012, 47, 110.

17. Branen, A. L.; Davidson, P.; Salminen, S.; Thorngate III, J. H.; Food Additives.: Marcel Dekker, Inc., New York, 2002.

18. Meyerhof. W.; Em Food and Nutrition Board, Institute of Medicine, National Academy of Sciences. 4th edition. XXXII. National Academy Press, Washington, D.C, 1996.

19. Tarayre, C.; Nguyen, H-T.; Brognaux, A.; Delepierre, A.; De Clercq, L.; Charlier, R.; Michels, E.; Meers, E.; Delvigne, F.; Sensors 2016, 16, 797.

20. Samuell, C. T.; Kasidas, G. P.; Ann. Clin. Biochem. 1995, 32, 112.

21. Robinson, H.; Proc. Cambr. Phil. Soc. 1889, 6, 360.

22. Beavon. J.; Heatley, N. G.; J. Gen. Microbiol. 1962, 31, 167.

23. Shinano, H.; Sakai, M.; Bull. Jap. Soc. Sci. Fish 1975, 41, 913.

24. Lowestam, H. A.; Weiner, S.; Em Biomineralization and Biological Metal Accumulation; Westbroek, P., de Jong, E. W., eds.; Riedel: Dordrecht, 1983, p. 191.

25. Grenabo, L.; Brorson, J. E.; Hedelin, H.; Pettersson, S.; J. Urol. 1984, 132,795 .

26. Perez-Garcia, I.; Rivadeneyra, M. A.; Ramos-Cormenzana, A.; Chemosphere 1989, 18, 1633.

27. Okorokov, L. A.; Lichko, L. P.; Kholodenko, V. P.; Kadoitseva, V. M.; Petrikevich, S. B.; Zaichkin, E. I.; Karimova, A. M.; Folia Microbiol. 1975, 20, 460.

28. Perez-Garcia, I.; Rivadeneyra, M.A.; Quevedo-Sarmiento, J.; RamosCormenzana, A.; Chemosphere 1990, 20, 243.

29. Gonzalez-Muñoz, M. T.; Arias, J. M.; Montoya, E.; Rodriguez-Gallego, M.; Chemosphere 1993, 26, 1881.

30. Ben Omar, N.; Martinez-Canamero, M.; Gonzalez-Munoz, M.; Arias, J. M.; Huertas, F.; Chemosphere 1995, 30, 2387.

31. Da Silva, S. D.; Bernet, N.; Delgen, J. P.; Moletta, R.; Chemosphere 2000, 40, 1289 .

32. Ben Omar, N.; Entrena, M.; Gonzalez-Muñoz, M. T.; Arias, J. M.; Huertas, F.; Geomicrobiol. J. 1994, 12, 81 .

33. Ben Omar, N.; Gonzalez-Muñoz, M. T.; Peñalver, J. M. A.; Chemosphere 1998, 36, 475.

34. Rivadeneyra, M. A.; Gonzalez-Lopez, J.; Ramos-Cormenzana, A.; Folia Microbiol. 1985, 80, 55 .

35. Rivadeneyra, M. A.; Pérez-Garcia, I.; Ramos-Cormenzana, A.; Curr. Microbiol. 1992a, 24, 343.

36. Rivadeneyra, M. A.; Perez-Garcia, A. I.; Ramos-Cormenzana, A.; Geomicrobiol. J. 1992b, 10, 125.

37. Gonzalez-Muñoz, M. T.; Ben Omar, N.; Martinez-Cañamero, M.; Rodriguez-Gallego, M.; Lopez-Galindo, A.; Arias J. M.; J. Crystal Growth 1996, 163, 434.

38. Nelson. B.; Struble, J.; McCarthy, G.; Can. J. Microbiol. 1991, 37, 978.

39. Sadowski, R. R.; Prywer, J.; Torzewska, A.; Cryst. Res. Technol. 2014, $49,478$. 
40. Sun, J.; Chen, L.; Wang, X.; Cao, S.; Fu, W.; Zheng, W.; Synth. React. Inorg. Metal-Org. Nano-Met. Chem. 2012, 42, 445.

41. Chen, L.; Shen, Y., Xie, A.; Huang, F.; Zhang, W.; Liu, S.; Crystal Growth Design 2010, 10, 2073.

42. Sinha, A.; Singh, A.; Kumar, S.; Khare, S. K.; Ramanan, A.; Water Res. 2014, 54, 33.

43. Battistoni, P.; Fava, G.; Pavan, P.; Musacco, A.; Cecechi, F.; Water. Res. 1997, 31, 2925.

44. Adroher, F. J.; Osuna, A.; Lupiañez, J. A.; Chemosphere 1988, 17, 609

45. Tian, C.Y.; Ye, X.; Xu, Y. Y.; Hua, W.; Wang, W. Q.; Wu, S.; Paul, C.; Cheng, Y. Int. J. Agric. Biol. Eng. 2017, 10, 142.

46. Liu, Y. H.; Rahman, M. M.; Kwag, J-H.; Kim, J-H.; Ra, C. S.; AsianAust. J. Anim. Sci. 2011, 24, 1699.

47. Gonzalez-Muñoz, M. T.; Entrena, M.; Ben Omar, N.; Huerta, F.; Arias, J. M.; Geomicrobiol. J. 1994, 26, 279.

48. Jimenez-Lopez, C.; Jroundi, F.; Rodríguez-Gallego, M.; Arias, J. M.; Gonzalez-Muñoz, M. T. Em Comm. Curr. Res. Educ. Topics. Trends Appl. Microbiol.; Méndez-Vilas, A., ed.; FORMATEX 2007, 1, 143.

49. González-Muñoz, M. T.; Rodriguez-Navarro, C.; Martínez-Ruiz, R.; Arias, J. M.; Merroun, M. L.; Rodriguez-Gallego, M.; Geological Society, London, Special Publications 2010, 336, 31.

50. Dana, E. S. Em Dana's Mineralogy; Ford, W. E., ed.; $4^{\text {th }}$ ed., John Wiley and Sons: New York, 1966.

51. Mestres, G.; Aguilera, F. S.; Manzanares, N.; Sauro, S.; Osorio, R.; Toledano, M.; Ginebra, M. P.; Inter. Endodontic. J. 2014, 47, 127.

52. Fournier, J. A., Paine III, J. B.; US6289898 B1 2001; Bridge, P. J.; Mineral Mag. 1973, 39, 467.

53. Rivadeneyra, M. A.; Ramos-Cormenzana, A.; García-Cervigón, A.; Mineral. J. 1987, 13, 443.

54. Rivadeneyra, A.; Gonzalez-Martinez, A.; Gonzalez-Lopez, J.; MartinRamos, D.; Toledo, M. V.; Rivadeneyra, M. A.; Inter. J. Environ. Res. Public Health 2014, 11, 3689.

55. Del Moral, A.; Rivadeneyra, M. A.; Roldán, E.; Perez-García, I.; RamosCormenzana, A.; García-Cervigón, A.; Urol. Int. 1989, 44, 222.

56. Omura, S.; Tanaka, Y.; Kitao, C.; Tanaka, H.; Iwai, Y.; Antimicrob. Agents Chemother. 1980, 18, 691.

57. Yu, X.; Qian, C.; Wang, X.; Asian J. Chem. 2014, 26, 7477.

58. Yu X.; Qian, C.; Wang, X.; Sci. Adv. Mater. 2015, 7, 1730.

59. Demeester, J.; De, S. S.; Sanders, N.; WO2002083167 A2 2002

60. Yang, H.; Martinelli, L.; Tasso, F.; Sprocati, A. R.; Pinzari, F.; Liu, Z.; Downs, R. T.; Sun, H. J.; Am. Mineral. 2014, 99, 1761.

61. Kamnev, A. A.; Antonyuk, L. P.; Colina, M.; Chernyshev, A. V.; Ignatov. V. V.; Monatsh. Chem. 1999, 130, 1431.

62. Durán, N.; Nunes O. D. S.; Braz. J. Med. Biol. Res. 1990, 23, 1289.

63. Durán, N.; Haun, M.; Da Silva, L.P.; Pisani, R.; Nunes, O. D. S.; SouzaBrito, A.; M.N. Mazetto, M. N.; Braz. J. Med. Biol. Res. 1990, 23, 1303.

64. Justo, G. Z.; Durán, N.; Queiroz, M. L. S.; Eur. J. Phamacol. 2000, 388, 219226.

65. Justo, G. Z.; Durán, N.; Queiroz, M. L. S.; Immunopharmacol. Immunotoxicol. 2003, 25, 305.

66. Santos, E. M.; Durán, M.; Tasic, L.; Proc. 17th Scientific Initiation Congress, Campinas, Brasil, 2009, 17, 178, E0536.

67. De Oliveira, J. A.; Nunes, O. D. S.; Nunes, I. S.; Macedo, A. M.; Botacin, P. R.; Durán, N.; Proc. 8th Intern. Conf. on AIDS, Amsterdam, Netherlands, PuB 7394, 1992, 8, 114.

68. Durán, N.; Drugs Future 1993, 18, 327.

69. Durán, N.; Justo, G.Z.; Queiroz, M. L. S.; Vieira-Matos, A. N.; Rettori, O.; Intern. J. Mol. Med. 1999a, 4 (Suppl.1): S-49, 280.

70. Durán, M.; Marcato, P. D.; Durán, N.; Proc. 7th Congress SBPMat., Guaruja, Brasil, CD-ROM, 2008a.

71. Durán, M.; Marcato, P. D.; Costa, F. T. M.; Durán, N.; Tasic. L.; Proc. 2nd World Conference on Magic Bullets (Ehrlich II) Nuremberg, Germany, L2008_46584899, 2008b, 2, A-319.
72. Durán, N.; Gowen, B. B.; Costa, F. T. M.; Justo, G. Z.; Brocchi, M.; Nunes, O. S.;Nunes, I. S.; Antiviral. Res. 2009a, 83, 143.

73. Durán, N.; Gowen, B. B.; Justo, G. Z.; Lopes, S.; Costa, F. T. M.; Nunes, O. S., Nunes, I. S.; Durán, M.; Marcato, P. D.; Tasic L.; Proc. 7th International Congress of Pharmaceutical Sciences (CIFARP), Riberão Preto, Brasil, CD-ROM, 2009c.

74. Durán, N.; Gowen, B. B.; Justo, G. Z.; Nunes, I. S.; Durán, M.; Marcato, P. D.; Tasic, L.; Proc. Indo - US Workshop on Nanotechnology Applications and Implications - 2009, Tarnaka, India, L-16, 2009.

75. Durán, N.; Durán, M.; Marcato, P. D.; Tasic, L.; Costa, F. T. M.; Proc. NanoBio Europe, Grenoble, France, CD ROM, 2009 b.

76. Fávaro, W. J.; Billis, A.; Nunes, I. S.; Durán N.; J. Urol. 2012a, 187, E231.

77. Durán, N.; Drugs Future 1997, 22, 454.

78. Durán, N.; Justo, G. Z.; Queiroz, M. L. S.; Vieira-Matos, A. N.; Rettori, O.; Intern. J. Mol. Med. 1999b, 4 (Suppl.1), S-49, 280.

79. Durán, M.; Tasic, L.; Costa, F.T.M.; Lopes, S.; Marcato, P. D.; Durán N.; Proc. Workshop International on Nanomaterials and Functional Materials, Campinas, Brasil, CD-ROM, 2009b.

80. Durán, N.; Marcato, P. D.; Dias, Q. C.; Garcia, P. V.; Fávaro, W. J.; Lima, A. C. S.; Proc. 12th International Conference on Nanostructured Materials NANO 2014, Moscow, Russia, 12: Sec.08, 2014, 12, 71.

81. Fávaro, W. J.; Durán, M.; Reis, L. O.; Durán, N.; Proc. National Conference on Synthesis Characterization \& Simulation in Nanoscience \& Nanotechnology NANOSIM-2012, Calcutta, India, 2012c, 1, 18.

82. Reis, L.; Ferreira, U. I.; Billis, A.; Castello, A.; Nunes, I.; Durán, N.; Cagnon, V.; Favaro, W. J.; J. Urol. 2011, 185, e2000.

83. Justo, G. Z., Durán, N., and Queiroz, M. L. S.; Intern. J. Mol. Med. 2007, 4 (Suppl.1), S-49, 279.

84. Garcia, P. V.; Seiva, F. R. F.; Carniato, A. P.; de Mello Jr., W.; Durán, N.; Macedo, A. M.; de Oliveira, A. G.; Romih, R.; Nunes, I. S.; Nunes, O. S.; Fávaro, W. J.; BMC Cancer 2016, 16, 422.

85. Garcia, P.V.; Apolinário, L. M.; Böckelmann, P. K.; Nunes, I. S.; Durán, N.; Fávaro W. J.; Int. J. Clin. Exp. Pathol. 2015, 8, 4427.

86. Fávaro, W. J., Nunes, O. S.; Seiva, F. R. F.; Nunes, I. S.; Woolhiser, L. K.; Durán, N.; Lenaerts A. J.; Infect. Agents Cancer 2012b, 7, 14.

87. Dias, Q. C.; Nunes, I. S.; Garcia, P. V.; Favaro, W. J.; Int. Braz. J. Urol. 2016, 42, 942.

88. Apolinario, L. M.; Garcia, P. V.; Nunes, I. S.; Durán, N.; Fávaro, W. J.; Proc. $34^{\text {th }}$ Brazilian Urology Congress, Natal, Brasil, 2013, 34, 713.

89. Pereira, M. N.; dos Santos, M. M.; Nunes, I. S.; Durán, N.; Fávaro, W. J.; Garcia. P. V.; Proc. 24th Congress on Scientific Initiation, UNICAMP, Campinas, Brazil, 10.19146/pibic-2016-51054. 2016, 24, 15015.

90. Fávaro, W. J. Proc. FAPESP (Brazil) 12:11002-1, 2012.

91. Marcato, P. D.; Lima, A. C. S.; Nunes, I.; Durán, N.; Fávaro, W. J.; Proc. 9th. International Congress Pharmaceutical Sciences (CIFARP), Riberão Preto, Brasil, 2013, 9, PC51.

92. Lima, A. C. S.; Proc. FAPESP (Brazil) 12: 16880-7, 2012.

93. Lima, A. C. S.; Dias, Q. C.; Matsumoto, M. Y.; da Rocha, A. B. M. V.; Durán, N.; Fávaro, W. J.; Proc. 17th Meeting Brazilian Society for Cell Biology and Dynamics Cell Biology in Health and Disease, Foz do Iguaçu, Brasil, 2014a, 17, A83.

94. Lima, A. C. S.; Dias, Q. C.; Matsumoto, M. Y.; da Rocha, A. B. M. V.; Durán, N.; Fávaro, W. J.; Proc. 17th Meeting Brazilian Society for Cell Biology and Dynamics Cell Biology in Health and Disease, Foz do Iguaçu, Brasil, 2014b, 17, A114.

95. Durán, N.; Fávaro, W. J.; Proc. Symposium at Advanced Center for Chronic Diseases (ACCDiS), Santiago, Chile, 2016, 16, 35.

96. Cyrino, L. T.; Monografia, Universidade Federal de Viçosa, Brasil, 2008.

97. Santiago, M. E. B.; Silveira, Neto, L.; Costa, A. E.; Prado, M. D.; Andrade, M. M. C.; Somenzari, M. A.; Ciarlini, P. C.; De Lima, V. M.; Acta Tropica 2013, 127, 174. 
98. Melo, L. M.; Andrade, M. С. M.; De Lima, V. M. F.; Proc. 16th Annual Meeting of the Brazilian Society of Protozoology, Foz do Iguaçu, Brasil, 2010a, 16, 173.

99. Melo, L. M.; Andrade, M. C. M.; De Lima, V. M. F.; 35th Congress of the Brazilian Society for Immunology, Porto Alegre, Brasil, 2010b, 35, p. IR071.

100. Melo, L. M.; Silva, K. L. O.; Perosso, J.; Sanches, L. C.; Andrade, M. C. M.; De Lima, V. M. F.; Proc. ALAI, Lima. Peru, X Congress of the Latin America Association of Immunology-ALAI, Lima, Peru, 2012a, 10, 104.

101. Melo, L. M.; Silva, K. L. O.; Oliveira, B. B.; Somenzari, M. A.; Perosso, J.; De Lima, V. M. F.; Veterinária e Zootecnia (UNESP) 2012b, 19, 126.

102. Melo, L. M.; Sanches, L. C.; Silva, K. L. O.; Borges, J. P.; Oliveira, B. B.; Somenzari, M. A., De Lima V. M. F.; Proc. 37th Congress of The Brazilian Society of Immunology, Campos do Jordão, Brasil, 2012c, 37, 104.

103. Melo, L. M.; Sanches, L. C.; Perosso, J.; Silva, K. L. O.; De Lima, V. M. F.; Fifth Congress on Leishmaniasis, Porto de Galinhas, Brasil, 2013, 5, (298) P396.
104. Melo, L. M.; Perosso, J.; Almeida, B. F.; Silva, K. L.; Somenzani, M. A.; de Lima, V. M.; Intern. Immunopharmacol. 2014, 18, 373.

105. Silveira Neto, L.; Cherlier, M. G. S.; De Lima, V. M. F.; Proc. XXXIV Congresso da Sociedade Brasileira de Imunologia, Salvador, Brasil, 2009, 34, IPH 053.

106. Somenzari, M. A.; Melo, L. M.; Andrade, M. C. M.; Oliveira, B. B.; De Lima, V. M. F.; Veterinária e Zootecnia (UNESP) 2011, 18, 51.

107. Somenzari, M. A.; Oliveira, B. B.; Melo, L. M.; Andrade, M. C. M.; Silva, K. L. O.; De Lima, V. M. F.; Veterinária e Zootecnia (UNESP) 2012, 19, 105.

108. De Lima, V. M. F.; Silveira Neto, L.; Alexandre, E. C.; Proc. Symp. IberoAmerican of Emerging and Re-emerging Zoonotic Diseases, Punta del Este, Uruguay, CD-Rom, 2011.

109. De Lima, V. M. F.; Santiago, M. E. B.; Silveira Neto, L.; Alexandre, E. C.; Munari, D. P.; Andrade, M. C.; Somenzari M. A.; Ciralini P C; Proc. Fifth Congress on Leishmaniasis, Porto de Galinhas, Brazil, 2013, 5, 396. 